\title{
EFFECT OF SALT AND STORAGE TEMPERATURE ON BEEF SAUSAGE QUALITY
}

\author{
R. Luna, M. A. Hashem*, M. S. Ali, M. M. Hossain, M. A. K. Talukder and \\ M. S. Islam \\ Department of Animal Science, Bangladesh Agricultural University \\ Mymensigh-2202, Bangladesh
}

\begin{abstract}
The experiment was conducted to find out the effect of salt and storage temperature on the quality of sausage. For this purpose sausage samples were divided into two portions. One is called fresh sausage and another is preserved sausage at different temperature. Then the fresh samples as well as the preserved samples were divided into four subdivisions, treated with different salt levels and e.g. control group- $0 \%$ and the others are $1.5 \%, 3 \%$ and $5 \%$ of salt concentration. The preserved samples were stored at $4^{\circ} \mathrm{C}$ and $-20^{\circ} \mathrm{C}$. Samples preserved at $4{ }^{\circ} \mathrm{C}$ were stored in the refrigerator for 21 days and were analyzed on $7^{\text {th }}, 14^{\text {th }}$ and $21^{\text {th }}$ day and on the other hand samples preserved at $-20^{\circ} \mathrm{C}$ were stored in the freezer for 60 days and were analyzed on $15^{\text {th }}, 30^{\text {th }}, 45^{\text {th }}$ and $60^{\text {th }}$ day. Dry matter and Ash content of all the samples increased with the advancement of storage time and salt concentration level. Dry matter in fresh sample was less compared to preserved samples. Crude protein (CP) percent of fresh samples were $23.13,22.63,22.48$ and 22.44 at different salt concentration level. The values of $\mathrm{CP}, \mathrm{DM}, \mathrm{Ash} \&$ Fat also varied among the samples significantly $(\mathrm{P}<0.01)$. Sausage can be preserved for 60 days in different techniques with different changes in the quality. Highly significant difference was observed in preserved samples than in fresh samples at different salt levels. Fresh sausage treated with $1.5 \%$ salt found to be more acceptable in terms of sensory evaluation.
\end{abstract}

Key Words: Beef sausage, Salt, Forzen saugage, Refrizerated sausage

\section{INTRODUCTION}

Meat is recognized as a highly nutritious food, being an excellent source of high quality protein. Meat is essential to build a healthy nation by providing energy, health and vigor. Meat product like sausage also contains all of these nutrients. Bangladesh is densely populated country. Now-a-days every people are busy with their works. So they have not enough time to prepare food. In this case sausage can help the people, as sausage is a ready-made food.

*Corresponding author:- E-mail: hashem_mdabul@yahoo.com, Mobile: 01721-310621 
Studies on meat consumption in last decade have shown nutritional value of a product is a major factor in consumer preference (Angulo and Gil, 2007; Fonseca and Salay, 2008). Cardiovascular disease (CVD) accounts for $30 \%$ of all deaths across the world (World Health Organization, 2009). Hypertension a term which describes high blood pressure has high a global prevalence. Many studies have shown a link between a high intake of dietary sodium and hypertension (Dahl, 1972). The main source of sodium (75\% of total dietary intake) in most of our diets has been shown by Apaydn et al., 2003 to come from processed food.

Aggett et al. (2005) reported that processed meats contain high levels of animal fat which have been associated with increased risk of promoting obesity, diabetes and also cancers especially colon cancers.

Salt is a vital ingredient in processed meat as it has numerous technological benefits such as preservation, taste enhancement and water holding capacity (Durack et al., 2008). Water holding capacity is defined as the ability of a food to enclose liquid within a three dimensional structure (Chantrapornchai and McClements, 2002). Salt is able to increase the water holding capacity of a meat product by extracting myofibrillar proteins which associate into a gel when heated (Foegeding and Lanier, 1987).

However, it is still important to obtain an acceptable limit at which salt can be reduced from processed meat products without negatively impacting functionality, product quality or adversely affect sensorial acceptability, so as to enhance the health status of processed meats. Research work carried out by Tobin et al. $(2012 \mathrm{a}, \mathrm{b})$ have shown that salt content can be successfully reduced in processed meat products such as burgers and frankfurters.

The aim of preservation is not only to retard the food spoilage but also to control undesirable changes of wholesomeness, nutritive value and growth of microorganisms (Fennema, 1975). Freezing is the only known method by which Sausage can be preserved in a condition similar to their normal state. Freezing at different temperature affect the sausage quality.

The present research work was conducted with a view to identify the acceptable salt level of sausage, the quality of sausages and to find the effect of preservation temperature on the chemical composition of sausage.

\section{MATERIALS AND METHODS}

\section{Collection of meat}

Fresh samples were collected from cattle slaughtered in Sheep and Goat Farm, Department of Animal Science, Bangladesh Agricultural University, Mymensingh. Chemical analysis was carried out in the Animal Science Laboratory, Department of Animal Science, BAU, Mymensingh. 


\section{Sample preparation}

All visible fat and connective tissue were trimmed off as far as possible with the help of knife and the sample was cut into small pieces. Beef was grinded with the help of meat grinder, then mixed with some spices i.e. chili powder, turmeric powder etc. The meat was aliquot into 4 parts. Each part was mixed with salt at $0 \%, 1.5 \%, 3 \%, 5 \%$ respectively according to weight basis. Meat from each mixture was taken and wrapped with small square pieces of plastic as a casing. Both end of bag were tied with thread for not entering water and were then placed in to boiling water for cooking. These procedure were made for three times to prepare sample to analyze the first one as fresh basis and the other two were kept in two different freezes at $4^{\circ} \mathrm{C}$ and $-20^{\circ} \mathrm{C}$, respectively for further analysis in various days interval of preservation; it was named the refrigerated sausage. The second portion (freezing temperature $-20^{\circ} \mathrm{C}$ ) of the sausage was named the frozen sausage. Then the samples were packaged in polyethylene bags separately and was kept into the freeze.

\section{Defrosting process}

After storing 7, 14 and 21 and for 15, 30, 45 and 60 days, the samples were defrosted by air, water and microwave oven to prepare for chemical analysis.

\section{Proximate composition}

Proximate composition such as Dry Matter (DM), Ether Extract (EE), Crude Protein (CP) and Ash were carried out according to the methods (AOAC, 1995). All determination was done in triplicate and the mean value was reported.

\section{pH measurement}

$\mathrm{pH}$ value of meat was measured using $\mathrm{pH}$ meter from meat homogenate. The homogenate was prepared by blending $2 \mathrm{~g}$ of meat with $10 \mathrm{ml}$ distilled water.

\section{Statistical analysis}

Data were analyzed statistically using the analysis of variance technique in a computer using SAS statistical computer package programmed in accordance with the principle of Completely Randomized Design (CRD). Duncan's Multiple Range Test was done to compare variations between treatments where ANOVA showed significant differences.

\section{RESULTS AND DISCUSSION}

\section{Proximate Composition \\ Dry matter}

Dry matter content of sausage at different salt concentration, storage temperature and days are presented in Table 1 . Dry matter of fresh sausage of $0 \%$ salt was $29.57 \%$, refrigerated sausage and frozen sausage of $0 \%$ salt at 21 days and 60 days were $29.84 \%$ and $30.84 \%$, respectively. Dry matter of fresh sausage of $1.5 \%$ salt was $29.63 \%$ and refrigerated and frozen sausage of $1.5 \%$ salt at 21 and 60 days were $29.47 \%$ and $30.37 \%$, respectively. Dry matter content of fresh sausage of $3.0 \%$ salt was $30.0 \%$ and refrigerated 
and frozen sausage of $3.0 \%$ salt at 21 and 60 days were $30.52 \%$ and $31.29 \%$, respectively. Dry matter of fresh sausage of $5.0 \%$ salt was $31.59 \%$ and refrigerated and frozen sausage of $5.0 \%$ salt at 21 and 60 days were $31.44 \%, 32.44 \%$, respectively. There were little changes of dry matter content during storage time. Dry matter content was higher with the increase of storage time and salt concentration in all samples. The loss of moisture probably associated to increased dry matter. Dry matter increased for the moisture loss of sausage with advanced of storage time during freezing. Jihad et al., 2009 reported that Mortedella plan and Mortedella with olive beef sausage contain $34.5 \%$ and $36.8 \%$ dry matter, respectively, which are partially matched with our findings.

\section{Ash}

Ash was also analyzed up to the end of the storage period of 60 days and the results are presented in Table 1. Ash of fresh sausage of $0 \%$ salt was $1.09 \%$, refrigerated and frozen sausage of $0 \%$ salt at 21 days and 60 days were $1.13 \%$ and $1.22 \%$, respectively. Ash of fresh sausage of $1.5 \%$ salt was $1.05 \%$ and refrigerated and frozen sausage of $1.5 \%$ salt at 21 and 60 days were $1.06 \%$ and $1.20 \%$, respectively. Ash of fresh sausage of $3.0 \%$ salt was $1.00 \%$ and refrigerated and frozen sausage of $3.0 \%$ salt at 21 and 60 days were $1.03 \%$ and $1.08 \%$, respectively. Ash of fresh sausage of $5.0 \%$ salt was $0.98 \%$ and refrigerated and frozen sausage of $5.0 \%$ salt at 21 and 60 days were $1.02 \%$ and $1.09 \%$, respectively. Ash value increased with the increase of storage time and salt concentration. Jihad et al., 2009 also reported that Mortedella plan beef sausage contains 2.2\% ash which is consistent with our findings.

\section{Crude protein}

Crude protein $(\mathrm{CP})$ content was also determined at the end of the storage period of 60 days and the results are presented in Table 1 . CP of fresh sausage of $0 \%$ salt was $23.31 \%$, refrigerated sausage and frozen sausage of $0 \%$ salt at 21 days and 60 days were $21.55 \%$ and $20.33 \%$, respectively. CP of fresh sausage of $1.5 \%$ salt was $22.63 \%$ and refrigerated and frozen sausage of $1.5 \%$ salt at 21 and 60 days were $22.11 \%$ and $21.15 \%$, respectively. CP of fresh sausage of $3.0 \%$ salt was $22.48 \%$ and refrigerated and frozen sausage of $3.0 \%$ salt at 21 and 60 days were $21.62 \%$ and $23.53 \%$, respectively. CP of fresh sausage of $5.0 \%$ salt was $22.44 \%$ and refrigerated and frozen sausage of $5.0 \%$ salt at 21 and 60 days were $21.45 \%$ and $20.51 \%$, respectively. The CP content decreased due to loss of protein during storage in those samples may be related with loss of sarcoplasmic protein, osmosis and poor water holding capacity. Jihad et al., 2009 reported that Mortedella plan and Mortedella with olive beef sausage contain $13.1 \%$ and $12.1 \%$ crude protein, respectively which are inconsistent with our findings. It might be due to variation of sausage type.

\section{Fat}

Fat content of samples was also analyzed up to the end of the storage period of 60 days and the results are presented in Table 1 . Fat of fresh sausage of $0 \%$ salt sample was $8.85 \%$, refrigerated sausage and frozen sausage of $0 \%$ salt sample at 21 days and 60 days were $8.50 \%$ and $7.90 \%$, respectively. Fat of fresh sausage of $1.5 \%$ salt sample was $8.61 \%$ and refrigerated and frozen sausage of $1.5 \%$ salt sample at 21 and 60 days were $8.47 \%$ and 
$7.97 \%$, respectively. Fat of fresh sausage of $3.0 \%$ salt sample was $8.74 \%$ and refrigerated and frozen sausage of $3.0 \%$ salt sample at 21 and 60 days were $8.44 \%$ and $7.84 \%$, respectively. Fat of fresh sausage of $5.0 \%$ salt sample was $8.75 \%$ and refrigerated and frozen sausage of $5.0 \%$ salt samples at 21 and 60 days were $8.39 \% 7.79 \%$, respectively. Fat value of sausage decreased with advanced of storage time, temperature and salt concentration. Jihad et al., 2009 reported that Mortedella plan and Mortedella with olive beef sausage contain $14.8 \%$ and $17.9 \%$ fat, respectively which are inconsistent with our findings. It might be due to variation of sausage type.

Table 1. Proximate composition of saugage

\begin{tabular}{|c|c|c|c|c|c|c|c|c|c|}
\hline \multirow[t]{2}{*}{ Treatment } & \multirow[t]{2}{*}{ Parameters } & \multirow{2}{*}{$\begin{array}{c}\text { Fresh } \\
\text { sample }\end{array}$} & \multicolumn{3}{|c|}{ Refrigerated sample } & \multicolumn{4}{|c|}{ Frozen sample } \\
\hline & & & 7 Days & 14 Days & 21 Days & 15 Days & 30 Days & 45 Days & 60 Days \\
\hline \multirow[t]{6}{*}{$\mathrm{T}_{1}$} & $\mathrm{DM} \%$ & 29.57 & 29.46 & 29.65 & 29.84 & 29.96 & 30.15 & 30.34 & 30.84 \\
\hline & Ash \% & 1.09 & 1.11 & 1.12 & 1.13 & 1.16 & 1.18 & 1.17 & 1.22 \\
\hline & $\mathrm{CP} \%$ & 23.31 & 21.55 & 21.13 & 21.55 & 21.22 & 21.15 & 20.73 & 20.33 \\
\hline & Fat $\%$ & 8.85 & 8.53 & 8.52 & 8.50 & 8.23 & 8.22 & 8.20 & 7.90 \\
\hline & $\mathrm{pH}$ & 5.64 & 5.41 & 4.76 & 4.81 & 5.63 & 4.69 & 4.65 & 4.20 \\
\hline & CL\% & 27.67 & 29.19 & 29.16 & 29.17 & 31.19 & 31.17 & 31.16 & 32.16 \\
\hline \multirow[t]{6}{*}{$\mathrm{T}_{2}$} & $\mathrm{DM} \%$ & 29.63 & 29.64 & 29.72 & 29.47 & 30.14 & 30.22 & 29.97 & 30.37 \\
\hline & Ash \% & 1.05 & 1.09 & 1.09 & 1.06 & 1.14 & 1.11 & 1.15 & 1.20 \\
\hline & $\mathrm{CP} \%$ & 22.63 & 22.30 & 21.95 & 22.11 & 21.90 & 21.71 & 21.55 & 21.15 \\
\hline & Fat $\%$ & 8.61 & 8.54 & 8.43 & 8.47 & 8.24 & 8.13 & 8.27 & 7.97 \\
\hline & $\mathrm{pH}$ & 5.66 & 4.71 & 4.70 & 4.66 & 4.93 & 4.88 & 4.92 & 5.14 \\
\hline & CL\% & 24.63 & 27.35 & 29.06 & 29.03 & 29.35 & 31.03 & 31.06 & 32.06 \\
\hline \multirow[t]{6}{*}{$\mathrm{T}_{3}$} & DM\% & 30.00 & 30.40 & 29.97 & 30.52 & 30.90 & 30.47 & 30.79 & 31.29 \\
\hline & Ash\% & 1.00 & 1.030 & 0.98 & 1.03 & 1.08 & 1.09 & 1.03 & 1.08 \\
\hline & $\mathrm{CP} \%$ & 22.48 & 21.24 & 24.33 & 21.62 & 20.84 & 21.22 & 23.93 & 23.53 \\
\hline & Fat $\%$ & 8.74 & 8.48 & 8.49 & 8.44 & 8.18 & 8.19 & 8.14 & 7.84 \\
\hline & $\mathrm{pH}$ & 5.63 & 4.48 & 5.20 & 4.66 & 4.71 & 4.84 & 5.42 & 5.25 \\
\hline & CL\% & 23.02 & 27.53 & 28.64 & 27.49 & 29.53 & 29.16 & 30.64 & 31.64 \\
\hline \multirow[t]{6}{*}{$\mathrm{T}_{4}$} & DM\% & 31.59 & 31.57 & 31.43 & 31.44 & 32.07 & 31.93 & 31.94 & 32.44 \\
\hline & Ash\% & 0.98 & 0.99 & 0.99 & 1.02 & 1.04 & 1.07 & 1.04 & 1.09 \\
\hline & $\mathrm{CP} \%$ & 22.44 & 21.47 & 21.37 & 21.45 & 21.07 & 21.05 & 20.94 & 20.51 \\
\hline & Fat $\%$ & 8.75 & 8.46 & 8.47 & 8.39 & 8.09 & 8.17 & 8.09 & 7.79 \\
\hline & $\mathrm{pH}$ & 5.70 & 4.46 & 4.92 & 4.60 & 4.67 & 4.82 & 5.14 & 5.13 \\
\hline & CL\% & 22.63 & 25.35 & 26.71 & 25.12 & 27.35 & 27.12 & 28.71 & 29.71 \\
\hline
\end{tabular}

$\mathrm{T}_{1}=0 \%$ salt; $\mathrm{T}_{2}=1.5 \%$ salt concentration; $\mathrm{T}_{3}=3 \%$ salt concentration and $\mathrm{T}_{4}=5 \%$ salt concentration 
$p H$

$\mathrm{pH}$ value of samples was also analyzed up to the end of the storage period of 60 days and the results are presented in Table 1. $\mathrm{pH}$ of fresh sausage of $0 \%$ salt sample was 5.64, refrigerated sausage and frozen sausage of $0 \%$ salt sample at 21 days and 60 days were 4.81 and 4.20 , respectively. $\mathrm{pH}$ of fresh sausage of $1.5 \%$ salt sample was 5.66 and refrigerated and frozen sausage of $1.5 \%$ salt sample at 21 and 60 days were 4.66 and 5.14, respectively. $\mathrm{pH}$ of fresh beef sausage of $3.0 \%$ salt sample was 5.63 and refrigerated and frozen sausage of $3.0 \%$ salt sample at 21 and 60 days were 4.66 and 5.25, respectively. $\mathrm{pH}$ of fresh sausage of $5.0 \%$ salt sample was 5.70 and refrigerated and frozen sausage of $5.0 \%$ salt sample at 21 and 60 days were 4.60 and 5.13, respectively. $\mathrm{pH}$ value of sausage increased with the increase of storage time and decreased with advanced of temperature and salt concentration. Jihad et al., 2009 reported that Mortedella plan beef sausage contains $6.4 \mathrm{pH}$, respectively which is inconsistent with our findings. It might be due to variation of sausage type.

Table 2. Attributes on sensory evaluation of beef sausage

\begin{tabular}{l|c|c|c|c|c}
\hline & Acceptability of color & Juiciness & Flavor & Saltiness Taste & Overall impression \\
\hline $\mathrm{T}_{1}$ & $3.40^{\mathrm{b}} \pm 0.12$ & $4.60^{\mathrm{a}} \pm 0.12$ & $3.60^{\mathrm{b}} \pm 0.12$ & $0.00^{\mathrm{c}} \pm 0.00$ & $0.20^{\mathrm{d}} \pm 0.10$ \\
$\mathrm{~T}_{2}$ & $3.20^{\mathrm{b}} \pm 0.19$ & $4.00^{\mathrm{b}} \pm 0.00$ & $4.80^{\mathrm{a}} \pm 0.10$ & $4.60^{\mathrm{a}} \pm 0.12$ & $4.80^{\mathrm{a}} \pm 0.10$ \\
$\mathrm{~T}_{3}$ & $4.60^{\mathrm{a}} \pm 0.12$ & $3.00^{\mathrm{c}} \pm 0.16$ & $3.80^{\mathrm{b}} \pm 0.10$ & $2.40^{\mathrm{b}} \pm 0.12$ & $3.60^{\mathrm{b}} \pm 0.12$ \\
$\mathrm{~T}_{4}$ & $3.60^{\mathrm{b}} \pm 0.12$ & $2.00^{\mathrm{d}} \pm 0.00$ & $2.00^{\mathrm{c}} \pm 0.00$ & $0.40^{\mathrm{c}} \pm 0.12$ & $2.80^{\mathrm{c}} \pm 0.10$ \\
\hline
\end{tabular}

$\mathrm{T}_{1}=0 \%$ salt; $\mathrm{T}_{2}=1.5 \%$ salt concentration; $\mathrm{T}_{3}=3 \%$ salt concentration and $\mathrm{T}_{4}=5 \%$ salt concentration. Within same column having mean with different superscripts differ significantly $(\mathrm{P}<0.05)$

\section{Cooking loss}

Cooking loss of samples was also analyzed up to the end of the storage period of 60 days and the results are presented in Table 1 . Cooking loss of fresh sausage of $0 \%$ salt sample was $27.67 \%$, refrigerated sausage and frozen sausage of $0 \%$ salt sample at 21 days and 60 days were $29.17 \%$, and $32.16 \%$, respectively. Cooking loss of fresh sausage of $1.5 \%$ salt sample was $24.63 \%$ and refrigerated and frozen sausage of $1.5 \%$ salt sample at 21 and 60 days were $29.03 \%$ and $32.06 \%$, respectively. Cooking loss of fresh sausage of $3.0 \%$ salt sample was $23.02 \%$ and refrigerated and frozen sausage of $3.0 \%$ salt sample at 21 and 60 days were $27.49 \%$ and $31.64 \%$, respectively. Cooking loss of fresh sausage of $5.0 \%$ salt sample was $22.63 \%$ and refrigerated and frozen sausage of $5.0 \%$ salt sample at 21 and 60 days were $25.12 \%$ and $29.71 \%$, respectively. Cooking loss of sausage decreased with the increase of salt concentration but increased with advances of storage time and temperature.

\section{Sensory evaluation}

Table 2 shows the result of sensory evaluation of beef sausage. Fresh sausage samples were analyzed for their color, tenderness, juiciness, flavor, texture, coarseness, hardness, saltiness taste and overall impression by 5 panelists familiar with sausage evaluation. Panelists were selected among teachers. Sensory evaluation was carried out in individual booths under controlled conditions of light, temperature, and humidity. Prior to sample evaluation, all panelists participated in orientation sessions to familiarize with the scale 
attributes (off-odor, freshness, overall, and so on) of fresh sausage using an intensity scale. Sensory qualities of the samples were evaluated using a 5-point scoring method. Sensory scores were 5 for excellent, 4 for very good, 3 for good, 2 for fair, and 1 for poor. All samples were served in the Petri dishes and were returned for further chemical analysis. Sensory evaluation was accomplished at day 0 .

\section{Interaction effects}

Interaction effects of proximate composition, $\mathrm{pH}$ and cooking loss of sausage on storage time and salt concentration was shown in Table 3,4 and 5. There were little changes of dry matter content during storage time. Dry matter content increased with the increase of storage time salt concentration in all samples and differed significantly $(\mathrm{P}<0.01)$ among the parameters. Ash value increased with the increase of storage time salt concentration in all samples and differed significantly $(\mathrm{P}<0.01)$ among the parameters. The $\mathrm{CP}$ content decreased due to loss of protein during storage time in those samples might be related with the loss of sarcoplasmic protein, osmosis and poor water holding capacity and differed significantly $(\mathrm{P}<0.01)$ among the parameters. Fat value of sausage decreased with the advances of storage time, temperature and salt concentration and differed significantly $(\mathrm{P}<0.01)$ among the parameters. $\mathrm{pH}$ value of beef saugage increased with the advances of storage time and decreased with the increase of temperature and salt concentration and differed significantly $(\mathrm{P}<0.01)$ among the parameters. Cooking loss of beef sausage decreased with the advances of salt concentration but increased with the advances of storage time and temperature and differed significantly $(\mathrm{P}<0.01)$ among the parameters.

Table 3. Interaction effect of proximate composition, $\mathrm{pH}$ and cooking loss (CL) on salt concentration

\begin{tabular}{|c|c|c|c|c|c|c|c|c|c|c|c|c|}
\hline \multirow{2}{*}{ 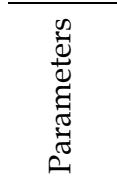 } & \multirow[b]{2}{*}{ 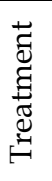 } & \multirow{2}{*}{$\begin{array}{c}\text { Fresh } \\
\text { sample }\end{array}$} & \multicolumn{3}{|c|}{ Refrigerated sample } & \multirow[b]{2}{*}{ 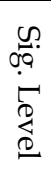 } & \multicolumn{5}{|c|}{ Frozen sample } & \multirow[b]{2}{*}{ 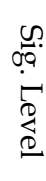 } \\
\hline & & & 7 Days & 14 Days & 21 Days & & $\begin{array}{l}\text { Fresh } \\
0 \text { Day }\end{array}$ & $\begin{array}{c}15 \\
\text { Days }\end{array}$ & $\begin{array}{c}30 \\
\text { Days }\end{array}$ & $\begin{array}{c}45 \\
\text { Days }\end{array}$ & $\begin{array}{c}60 \\
\text { Days }\end{array}$ & \\
\hline DM on & $\mathrm{T}_{1}$ & 29.57 & $29.46^{c}$ & $29.65^{b}$ & $29.84^{b c}$ & * & 29.57 & $29.96^{c}$ & $30.15^{b}$ & $30.34^{b}$ & $30.84^{\mathrm{bc}}$ & * \\
\hline \multirow[t]{3}{*}{ salt } & $\mathrm{T}_{2}$ & 29.63 & $29.64^{c}$ & $29.72^{b}$ & $29.47 \mathrm{c}$ & & 29.63 & $30.14^{c}$ & $30.22^{b}$ & $29.97 b$ & $30.37 \mathrm{c}$ & \\
\hline & $\mathrm{T}_{3}$ & 30.00 & $30.40^{\mathrm{b}}$ & $29.97 b$ & $30.52^{b}$ & & 30.00 & $30.90^{\mathrm{b}}$ & $30.47 \mathrm{~b}$ & $30.79 \mathrm{~b}$ & $31.29 \mathrm{~b}$ & \\
\hline & $\mathrm{T}_{4}$ & 31.59 & $31.57 \mathrm{a}$ & $31.43^{\mathrm{a}}$ & $31.44^{\mathrm{a}}$ & & 31.59 & $32.07 \mathrm{a}$ & $31.93^{a}$ & $31.94^{\mathrm{a}}$ & $32.44^{\mathrm{a}}$ & \\
\hline \multirow[t]{4}{*}{ Ash } & $\mathrm{T}_{1}$ & $1.09^{a}$ & $1.11^{\mathrm{a}}$ & $1.12^{\mathrm{a}}$ & $1.13^{\mathrm{a}}$ & * & $1.09 \mathrm{a}$ & $1.16^{\mathrm{a}}$ & $1.18^{\mathrm{a}}$ & $1.17 \mathrm{a}$ & $1.22^{\mathrm{a}}$ & * \\
\hline & $\mathrm{T}_{2}$ & $1.05^{\mathrm{ab}}$ & $1.09 \mathrm{ab}$ & $1.09 \mathrm{ab}$ & $1.06^{\mathrm{ab}}$ & & $1.05^{\mathrm{ab}}$ & $1.14^{\mathrm{ab}}$ & $1.11^{\mathrm{ab}}$ & $1.15^{\mathrm{ab}}$ & $1.20^{\mathrm{ab}}$ & \\
\hline & $\mathrm{T}_{3}$ & $1.00^{\mathrm{bc}}$ & $1.03^{b c}$ & $0.98^{\mathrm{ab}}$ & $1.03^{b}$ & & $1.00^{\mathrm{bc}}$ & $1.08^{\mathrm{bc}}$ & $1.09 \mathrm{~b}$ & $1.03^{\mathrm{b}}$ & $1.08^{\mathrm{b}}$ & \\
\hline & $\mathrm{T}_{4}$ & $0.98^{c}$ & $0.99 \mathrm{c}$ & $0.99 \mathrm{~b}$ & $1.02^{b}$ & & $0.98^{c}$ & $1.04^{c}$ & $1.07 \mathrm{~b}$ & $1.04^{b}$ & $1.09 \mathrm{~b}$ & \\
\hline \multirow[t]{4}{*}{$\mathrm{CP}$} & $\mathrm{T}_{1}$ & $23.31^{\mathrm{a}}$ & $21.55^{b}$ & $21.13^{c}$ & $21.55^{b c}$ & * & $23.14^{\mathrm{a}}$ & $21.22^{b}$ & $21.15^{b c}$ & $20.7^{c}$ & $20.3^{c}$ & * \\
\hline & $\mathrm{T}_{2}$ & $22.63^{b}$ & $22.30^{a}$ & $21.95^{b}$ & $22.11^{a}$ & & $21.56^{c}$ & $21.90^{a}$ & $21.71^{\mathrm{a}}$ & $21.55^{b}$ & $21.15^{b}$ & \\
\hline & $\mathrm{T}_{3}$ & $22.48^{b}$ & $21.24^{b}$ & $24.33^{a}$ & $21.62^{b}$ & & $22.48^{b}$ & $20.84^{b}$ & $21.22^{b}$ & $23.93^{a}$ & $23.53^{a}$ & \\
\hline & $\mathrm{T}_{4}$ & $22.44^{b}$ & $21.47^{b}$ & $21.37 \mathrm{bc}$ & $21.45^{c}$ & & $22.44^{b}$ & $21.07 \mathrm{~b}$ & $21.05^{c}$ & $20.94^{b c}$ & $20.51^{b c}$ & \\
\hline \multirow[t]{4}{*}{ Fat } & $\mathrm{T}_{1}$ & $8.85^{a}$ & 8.53 & 8.52 & 8.50 & * & $8.85^{\mathrm{a}}$ & 8.23 & 8.22 & 8.20 & 7.90 & * \\
\hline & $\mathrm{T}_{2}$ & $8.61^{b}$ & 8.54 & 8.43 & 8.47 & & $8.61^{b}$ & 8.24 & 8.13 & 8.27 & 7.97 & \\
\hline & $\mathrm{T}_{3}$ & $8.74^{\mathrm{ab}}$ & 8.48 & 8.49 & 8.44 & & $8.74^{\mathrm{ab}}$ & 8.18 & 8.19 & 8.14 & 7.84 & \\
\hline & $\mathrm{T}_{4}$ & $8.75^{\mathrm{ab}}$ & 8.46 & 8.47 & 8.39 & & $8.75^{\mathrm{ab}}$ & 8.09 & 8.17 & 8.09 & 7.79 & \\
\hline
\end{tabular}




\begin{tabular}{|c|c|c|c|c|c|c|c|c|c|c|c|c|}
\hline \multirow[b]{2}{*}{ 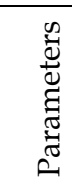 } & \multirow[b]{2}{*}{ 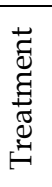 } & \multirow{2}{*}{$\begin{array}{c}\text { Fresh } \\
\text { sample }\end{array}$} & \multicolumn{3}{|c|}{ Refrigerated sample } & \multirow[b]{2}{*}{ 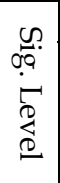 } & \multicolumn{5}{|c|}{ Frozen sample } & \multirow[b]{2}{*}{ 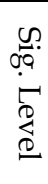 } \\
\hline & & & 7 Days & 14 Days & 21 Days & & $\begin{array}{l}\text { Fresh } \\
0 \text { Day }\end{array}$ & $\begin{array}{c}15 \\
\text { Days }\end{array}$ & $\begin{array}{c}30 \\
\text { Days }\end{array}$ & $\begin{array}{c}45 \\
\text { Days }\end{array}$ & $\begin{array}{c}60 \\
\text { Days }\end{array}$ & \\
\hline \multirow[t]{4}{*}{$\mathrm{pH}$} & $\mathrm{T}_{1}$ & 5.64 & $5.41^{\mathrm{ab}}$ & $4.76^{c}$ & $4.81^{\mathrm{a}}$ & * & 5.64 & $5.63^{a}$ & 4.69 & $4.65^{b}$ & $4.20^{c}$ & * \\
\hline & $\mathrm{T}_{2}$ & 5.66 & $4.71^{\mathrm{b}}$ & $4.70^{c}$ & $4.66^{\mathrm{b}}$ & & 5.66 & $4.93^{\mathrm{b}}$ & 4.88 & $4.92^{\mathrm{ab}}$ & $5.14^{\mathrm{b}}$ & \\
\hline & $\mathrm{T}_{3}$ & 5.63 & $4.48^{\mathrm{b}}$ & $5.20^{\mathrm{a}}$ & $4.66^{\mathrm{b}}$ & & 5.63 & $4.71^{\mathrm{b}}$ & 4.84 & $5.42^{\mathrm{a}}$ & $5.25^{\mathrm{a}}$ & \\
\hline & $\mathrm{T}_{4}$ & 5.70 & $4.46^{\mathrm{b}}$ & $4.92^{\mathrm{b}}$ & $4.60^{\mathrm{b}}$ & & 5.70 & $4.67 \mathrm{~b}$ & 4.82 & $5.14^{\mathrm{ab}}$ & $5.13^{\mathrm{b}}$ & \\
\hline \multirow[t]{4}{*}{$\mathrm{CL}$} & $\mathrm{T}_{1}$ & $27.67^{a}$ & $29.19 a$ & $29.16^{a}$ & $29.17 \mathrm{a}$ & * & $27.67 \mathrm{a}$ & $31.19 a$ & $31.17 \mathrm{a}$ & $31.16^{\mathrm{a}}$ & $32.16^{a}$ & * \\
\hline & $\mathrm{T}_{2}$ & $24.63^{b}$ & $27.35^{\mathrm{ab}}$ & $29.06^{\mathrm{b}}$ & $29.03^{b}$ & & $24.63^{b}$ & $29.35^{\mathrm{ab}}$ & $31.03^{a}$ & $31.06^{b}$ & $32.06^{b}$ & \\
\hline & $\mathrm{T}_{3}$ & $23.02^{c}$ & $27.53^{\mathrm{ab}}$ & $28.64^{c}$ & $27.49 c$ & & $23.02^{c}$ & $29.53^{\mathrm{ab}}$ & $29.16^{b}$ & $30.64^{c}$ & $31.64^{c}$ & \\
\hline & $\mathrm{T}_{4}$ & $22.63^{d}$ & $25.35^{b}$ & $26.71^{\mathrm{d}}$ & $25.12^{\mathrm{d}}$ & & $22.63^{d}$ & $27.35^{b}$ & $27.12^{c}$ & $28.71^{\mathrm{d}}$ & $29.71^{\mathrm{d}}$ & \\
\hline
\end{tabular}

$\mathrm{T}_{1}=0 \%$ salt; $\mathrm{T}_{2}=1.5 \%$ salt concentration; $\mathrm{T}_{3}=3 \%$ salt concentration and $\mathrm{T}_{4}=5 \%$ salt concentration. Mean with different superscripts within same column differ significantly. Significant at $1 \%$ level $(\mathrm{P}<0.01)$

Table 4. Interaction effect of proximate composition, $\mathrm{pH}$ and cooking loss (CL) of fresh and refrigerated sausage on storage time

\begin{tabular}{|c|c|c|c|c|c|c|}
\hline \multirow[t]{2}{*}{ Parameters } & \multirow{2}{*}{$\begin{array}{c}\text { Duration } \\
\text { (days) }\end{array}$} & \multicolumn{4}{|c|}{ Treatment } & \multirow{2}{*}{$\begin{array}{l}\text { Sig. } \\
\text { Level }\end{array}$} \\
\hline & & $\mathrm{T}_{1}$ & $\mathrm{~T}_{2}$ & $\mathrm{~T}_{3}$ & $\mathrm{~T}_{4}$ & \\
\hline \multirow[t]{4}{*}{$\mathrm{DM}$} & 0 & 29.57 & 29.63 & 30.00 & 31.59 & \multirow[t]{4}{*}{ NS } \\
\hline & 7 & 29.46 & 29.64 & 30.40 & 31.57 & \\
\hline & 14 & 29.65 & 29.72 & 29.97 & 31.43 & \\
\hline & 21 & 29.84 & 29.47 & 30.52 & 31.44 & \\
\hline \multirow[t]{4}{*}{ Ash } & 0 & 1.09 & 1.05 & 1.00 & 0.98 & \multirow[t]{4}{*}{ NS } \\
\hline & 7 & 1.11 & 1.09 & 1.03 & 0.99 & \\
\hline & 14 & 1.12 & 1.09 & 0.98 & 0.99 & \\
\hline & 21 & 1.13 & 1.06 & 1.03 & 1.02 & \\
\hline \multirow[t]{4}{*}{$\mathrm{CP}$} & 0 & $23.31^{a}$ & 22.63 & $22.48^{b}$ & $22.44^{a}$ & \multirow[t]{4}{*}{ * } \\
\hline & 7 & $21.55^{\mathrm{b}}$ & 22.30 & $21.24^{c}$ & $21.47 \mathrm{~b}$ & \\
\hline & 14 & $21.13^{b}$ & 21.95 & $24.33^{a}$ & $21.37 \mathrm{~b}$ & \\
\hline & 21 & $21.55^{c}$ & 22.11 & $21.62^{c}$ & $21.45^{b}$ & \\
\hline \multirow[t]{4}{*}{ Fat } & 0 & 8.85 & 8.61 & $8.74^{\mathrm{a}}$ & $8.75^{\mathrm{a}}$ & \multirow[t]{4}{*}{ * } \\
\hline & 7 & 8.53 & 8.54 & $8.48^{\mathrm{b}}$ & $8.46^{\mathrm{b}}$ & \\
\hline & 14 & 8.52 & 8.43 & $8.49 \mathrm{~b}$ & $8.47 \mathrm{~b}$ & \\
\hline & 21 & 8.50 & 8.47 & $8.44^{\mathrm{b}}$ & $8.39 \mathrm{~b}$ & \\
\hline \multirow[t]{4}{*}{$\mathrm{pH}$} & 0 & $5.64^{a}$ & $5.66^{a}$ & $5.63^{a}$ & $5.70^{a}$ & \multirow[t]{4}{*}{ * } \\
\hline & 7 & $5.41^{\mathrm{ab}}$ & $4.71^{b}$ & $4.48^{\mathrm{d}}$ & $4.46^{c}$ & \\
\hline & 14 & $4.76^{\mathrm{b}}$ & $4.70^{\mathrm{b}}$ & $5.20^{\mathrm{b}}$ & $4.92^{b}$ & \\
\hline & 21 & $4.81^{\mathrm{b}}$ & $4.66^{\mathrm{b}}$ & $4.66^{c}$ & $4.60 c$ & \\
\hline \multirow[t]{4}{*}{ CL } & 0 & $27.67 \mathrm{~b}$ & $24.63^{b}$ & $23.02^{c}$ & $22.63^{d}$ & \multirow[t]{4}{*}{ * } \\
\hline & 7 & $29.19 a$ & $27.35^{a}$ & $27.53^{b}$ & $25.35^{b}$ & \\
\hline & 14 & $29.16^{\mathrm{a}}$ & $29.06^{\mathrm{a}}$ & $28.64^{a}$ & $26.71^{a}$ & \\
\hline & 21 & $29.17^{a}$ & $29.03^{a}$ & $27.49 \mathrm{~b}$ & $25.12^{c}$ & \\
\hline
\end{tabular}

$T_{1}=0 \%$ salt $; T_{2}=1.5 \%$ salt concentration; $T_{3}=3 \%$ salt concentration and $T_{4}=5 \%$ salt concentration. Mean with different superscripts within same column differ significantly; Significant at $1 \%$ level $(\mathrm{P}<0.01)$, NS, indicates non significant 
Table 5. Interaction effect of proximate composition, $\mathrm{pH}$ and cooking loss (CL) of fresh and frozen sausage on storage time

\begin{tabular}{|c|c|c|c|c|c|c|}
\hline \multirow[t]{2}{*}{ Parameters } & \multirow{2}{*}{$\begin{array}{l}\text { Storage time } \\
\text { (Days) }\end{array}$} & \multicolumn{4}{|c|}{ Treatment } & \multirow[t]{2}{*}{ Sig. Level } \\
\hline & & $\mathrm{T}_{1}$ & $\mathrm{~T}_{2}$ & $\mathrm{~T}_{3}$ & $\mathrm{~T}_{4}$ & \\
\hline DM on storage & 0 & $29.57 \mathrm{~b}$ & $29.63^{b}$ & 30.00 & $31.59 \mathrm{~b}$ & * \\
\hline \multirow[t]{4}{*}{ time } & 15 & $29.96^{\mathrm{ab}}$ & $30.14^{\mathrm{ab}}$ & 30.90 & $32.07 \mathrm{ab}$ & \\
\hline & 30 & $30.15^{\mathrm{ab}}$ & $30.22^{\mathrm{ab}}$ & 30.47 & $31.93^{\mathrm{ab}}$ & \\
\hline & 45 & $30.34^{\mathrm{ab}}$ & $29.97 b$ & 30.79 & $31.94^{\mathrm{ab}}$ & \\
\hline & 60 & $30.84^{a}$ & $30.37 a$ & 31.29 & $32.44^{\mathrm{a}}$ & \\
\hline \multirow[t]{5}{*}{ Ash } & 0 & 1.09 & $1.05^{c}$ & $1.00^{c}$ & $0.98^{\mathrm{b}}$ & * \\
\hline & 15 & 1.16 & $1.14^{\mathrm{ab}}$ & $1.08^{\mathrm{ab}}$ & $1.04^{\mathrm{ab}}$ & \\
\hline & 30 & 1.18 & $1.11^{\mathrm{b}}$ & $1.09 a$ & $1.07 \mathrm{a}$ & \\
\hline & 45 & 1.17 & $1.15^{\mathrm{a}}$ & $1.03^{b c}$ & $1.04^{\mathrm{ab}}$ & \\
\hline & 60 & 1.22 & 1.20 & $1.08^{a}$ & $1.09 \mathrm{a}$ & \\
\hline \multirow[t]{5}{*}{$\mathrm{CP}$} & 0 & $23.14^{a}$ & $21.56^{\mathrm{ab}}$ & $22.48^{b}$ & $22.44^{a}$ & * \\
\hline & 15 & $21.22^{\mathrm{b}}$ & $21.90^{a}$ & $20.84^{c}$ & $21.07 \mathrm{~b}$ & \\
\hline & 30 & $21.15^{\mathrm{b}}$ & $21.71^{\mathrm{ab}}$ & $21.22^{\mathrm{c}}$ & $21.05^{b}$ & \\
\hline & 45 & $20.73^{c}$ & $21.55^{\mathrm{ab}}$ & $23.93^{a}$ & $20.94^{b}$ & \\
\hline & 60 & $20.33^{d}$ & $21.15^{b}$ & $23.53^{a}$ & $20.51^{b}$ & \\
\hline \multirow[t]{5}{*}{ Fat } & 0 & $8.85^{\mathrm{a}}$ & $8.61^{\mathrm{a}}$ & $8.74^{\mathrm{a}}$ & $8.75^{\mathrm{a}}$ & * \\
\hline & 15 & $8.23^{b}$ & $8.24^{b}$ & $8.18^{\mathrm{b}}$ & $8.09 \mathrm{~b}$ & \\
\hline & 30 & $8.22^{b}$ & $8.13 \mathrm{bc}$ & $8.19 b$ & $8.17 \mathrm{~b}$ & \\
\hline & 45 & $8.20^{b}$ & $8.27 \mathrm{~b}$ & $8.14^{\mathrm{b}}$ & $8.09 \mathrm{~b}$ & \\
\hline & 60 & $7.90^{\mathrm{b}}$ & $7.97 \mathrm{c}$ & $7.84^{\mathrm{c}}$ & $7.79 c$ & \\
\hline \multirow[t]{5}{*}{$\mathrm{pH}$} & 0 & $5.64^{a}$ & $5.66^{\mathrm{a}}$ & $5.63^{a}$ & $5.70^{a}$ & * \\
\hline & 15 & $5.63^{a}$ & $4.93^{c}$ & $4.71^{\mathrm{d}}$ & $4.67^{d}$ & \\
\hline & 30 & $4.69^{b}$ & $4.88^{c}$ & $4.84^{\mathrm{d}}$ & $4.82^{c}$ & \\
\hline & 45 & $4.65^{b}$ & $4.92^{c}$ & $5.42^{\mathrm{b}}$ & $5.14^{\mathrm{b}}$ & \\
\hline & 60 & $4.20^{\mathrm{b}}$ & $5.14^{\mathrm{b}}$ & $5.25^{c}$ & $5.13^{\mathrm{b}}$ & \\
\hline \multirow[t]{5}{*}{$\overline{C L}$} & 0 & $27.67 \mathrm{c}$ & $24.63^{c}$ & $23.02^{d}$ & $22.63 \mathrm{e}$ & * \\
\hline & 15 & $31.19 \mathrm{~b}$ & $29.35^{b}$ & $29.53^{c}$ & $27.35^{c}$ & \\
\hline & 30 & $31.17 \mathrm{~b}$ & $31.03^{\mathrm{ab}}$ & $29.16^{c}$ & $27.12^{d}$ & \\
\hline & 45 & $31.16^{b}$ & $31.06^{\mathrm{ab}}$ & $30.64^{b}$ & $28.71^{b}$ & \\
\hline & 60 & $32.16^{\mathrm{a}}$ & $32.06^{\mathrm{a}}$ & $31.64^{\mathrm{a}}$ & $29.71^{a}$ & \\
\hline
\end{tabular}

$\mathrm{T}_{1}=0 \%$ salt; $\mathrm{T}_{2}=1.5 \%$ salt concentration; $\mathrm{T}_{3}=3 \%$ salt concentration and $\mathrm{T}_{4}=5 \%$ salt concentration. Mean with different superscripts within same column differ significantly; Significant at $1 \%$ level $(\mathrm{P}<0.01)$

\section{REFERENCES}

AOAC. 1995. Official methods of analysis, 16th ed. Washington: Association Official Analytical Chemistry.

Angulo, A. M. and Gil, J. M. 2007. Risk perception and consumer willingness to pay for certified beef in Spain. Food Quality and Preference, 18(8): 1106-1117. 
Aggett, P. J., Antoine, J. M., Asp, N. G., Bellisle, F., Contor, L., Cummings, J. H. 2005. Process for the assessment of scientific support for claims on foods. Consensus on criteria. European Journal of Nutrition, 44(1): 1-31.

Apaydn, G., Ceylan, Z. G., Kaya, M. 2003. Some microbiological and chemical properties of bologna-type sausage samples from different brands. Turk-Veterinerlik-ve-HayvanclkDergisi, 27(6): 1299-1303.

Chantrapornchai, W. and McClements, D. J. 2002. Influence of $\mathrm{NaCl}$ on optical properties, large-strain rheology and water holding capacity of heat-induced whey protein isolate gels. Food Hydrocolloids, 16: 467-476.

Dahl, L. K. 1972. Salt and hypertension. American Journal of Clinical Nutrition, 25: 231-244.

Durack, E., Alonso-Gomez, M. and Wilkinson, M. G. 2008. Salt: a review of its role in food science and public health. Current Nutrition E Food Science, 4: 290-297.

Fonseca, M. C. and Salay, E. 2008. Beef, chicken and pork consumption and consumer safety and nutritional concerns in the city of Campinas, Brazil. Food Control, 19(11): 1051-1058.

Fennema, O. R. 1975. Introduction to food preservation. In: Principles of foodscience. (Ed.O.R.Fennema). Marcel Dekker, Inc. New York. pp. 1-7.

Foegeding, E. A. and Lanier, T. C. 1987. The contribution of nonmuscle proteins to texture of gelled muscle protein foods. Cereal Foods World, 32: 202-205.

Jihad M. Quasem, Ayman Suliman Mazahreh and Ali Faleh Al-Shawabkeh, 2009. Nutritive Value of Seven Varieties of Meat Products (Sausage) Produced in Jordan. Pakistan Journal of Nutrition, 8: 332-334.

Tobin, B., O'Sullivan, M. G., Hamill, R. and Kerry, J. P. 2012a. Effect of varying salt and fat levels on the sensory quality of beef patties. Meat Science, 91: 460-465.

Tobin, B., O'Sullivan, M. G., Hamill, R. and Kerry, J. P. 2012b. Effect of varying salt and fat levels on the sensory and physiochemical quality of frankfurters. Meat Science (Submitted).

World Health Organization. 2009. Cardiovascular Diseases.http://www.who.int/ mediacentre/factsheets/fs317/en/index.html;http://www.who.int/cardiovascular_ diseases/priorities/en/index.html. 